ks. Jan Dyduch

Uniwersytet Papieski Jana PaWŁa II w Krakowie

\title{
Adhortacja Amoris laetitia twórczą kontynuacją adhortacji Familiaris consortio?
}

Sobór Watykański II naucza: „Z małżeństwa wywodzi się rodzina, w której rodzą się nowi członkowie społeczności ludzkiej i stają się dzięki łasce Ducha Świętego przez chrzest dziećmi Bożymi, aby Lud Boży trwał przez wieki”. Troska Kościoła o małżeństwo i rodzinę jawi się także w jego nauczaniu, które sięga jego początków i trwa poprzez wieki aż do czasów współczesnych. W tych dziejach nauczania o małżeństwie i rodzinie znaczącą rolę odgrywa doktryna Vaticanum II, która była kontynuowana. Taką kontynuację stanowi nauczanie Jana Pawła II, w szczególności jego adhortacja Familiaris consortio, a także nauczanie papieża Franciszka, w tym jego adhortacja Amoris laetitia.

Adhortacja Amoris laetitia jest również kontynuacją adhortacji Familiaris consortio. W niniejszym artykule zamierzamy odpowiedzieć na pytanie: czy jest to kontynuacja twórcza? Odpowiadając na postawiony problem, zwrócimy uwagę jedynie na niektóre elementy nauczania występujące w obydwu adhortacjach. Są to:

1 Sacrosanctum Concilium Oecumenicum Vaticanum II, Constitutio dogmatica Lumen gentium de Ecclesia, 21.11.1964, AAS 57 (1965), s. 5-75; tekst łacińsko-polski: Sobór Watykański II, Konstytucja dogmatyczna o Kościele Lumen gentium, w: Sobór Watykański II, Konstytucje, dekrety, deklaracje, Poznań 2008, s. 144-263 [dalej: KK], n. 11. 
zakorzenienie w Piśmie św., miłość w małżeństwie i rodzinie, zadania rodziny i sprawa budząca najwięcej emocji, mianowicie duszpasterstwo związków nieregularnych.

\section{Małżeństwo i rodzina w Piśmie św. i nauczaniu Kościoła}

Autorzy obydwu przywołanych adhortacji często nawiązują do Pisma św. Jan Paweł II pisze: „Bóg stworzył człowieka na swój obraz i podobieństwo; powołując go do istnienia z miłości, powołał go jednocześnie do miłości”. Bóg, stwarzając człowieka, stworzył mężczyznę i kobietę, polecając im, aby zaludniali ziemię, czynili ją sobie poddaną, aby byli płodni i rozmnażali się (por. Rdz 1, 28). Tak więc małżeństwo to związek mężczyzny i kobiety dla zaludniania ziemi. Z woli Bożej związek ten jest nierozerwalny.

Jan Paweł II, mówiąc o porządku stworzenia, w szczególności o stworzeniu człowieka i ustanowieniu małżeństwa nierozerwalnego u początku dziejów ludzkości, przechodzi do nauczania Jezusa Chrystusa ${ }^{3}$. Pan Jezus objawia pełną prawdę o małżeństwie, przywołując jego początek: „Czy nie czytaliście, że Stwórca od początku stworzył ich jako mężczyznę i kobietę? (...) Co więc Bóg złączył, człowiek niech nie rozdziela” (Mt 19, 4b. 6b). Przywołany fragment wypowiedzi Jezusa zawarty jest w Jego rozmowie z faryzeuszami. Odwoływali się oni do Mojżesza, który zezwolił na rozwody. Pan Jezus tłumaczy im: „Przez wzgląd na zatwardziałość serc waszych pozwolił wam Mojżesz oddalać żony wasze; lecz od początku tak nie było" (Mt 19, 8).

To zatwardziałość serca ludzkiego sprawiła, że zamiar Boży został wypaczony. Pan Jezus nie tylko potwierdza pierwotną prawdę

2 Jan Paweł II, adhortacja apostolska Familiaris consortio [dalej: FC], 22.11.1981, n. 11.

3 Por. FC, n. 13. 
o małżeństwie, ale także obdarza człowieka łaską, aby pokonał zatwardziałość serca: „Objawia On pierwotną prawdę małżeństwa, prawdę o początku i wyzwalając człowieka od twardości serca, uzdalnia go do urzeczywistnienia w pełni tej prawdy"4. Taka prawda o małżeństwie jawi sięw nauczaniu Kościoła, którego poniekąd apogeum jest doktryna Vaticanum II. Małżeństwo jest wspólnotą charakteryzującą się nierozerwalnością. Kościół z całą mocą potwierdza i głosi nierozerwalność związku małżeńskiego jako prawdę zawartą w Bożym objawieniu. Bóg żąda nierozerwalności małżeńskiej i daje ją jako owoc, jako znak i wymóg miłości, absolutnie wiernej, jaką On darzy człowieka. Żąda, aby człowiek był posłuszny woli Chrystusa: „Co więc Bóg złączył, niech człowiek nie rozdziela” (Mt 19, 8) $)^{5}$.

Nierozerwalność małżeństwa zostaje w szczególniejszy sposób potwierdzona, a poniekąd przypieczętowana, przez jego sakramentalność. Każde małżeństwo, jako instytucja prawa Bożego ustanowiona przy początkach dziejów człowieka, charakteryzuje się świętością. Natomiast małżeństwo ochrzczonych jest sakramentem, gdyż Jezus Chrystus podniósł je do godności sakramentu. Naucza o tym adhortacja Familiaris consortio, włączając się w tradycyjną naukę Kościoła: „(...) małżeństwo ochrzczonych staje się w ten sposób rzeczywistym znakiem Nowego i Wiecznego Przymierza, zawartego we Krwi Chrystusa"6. Uzasadniając sakramentalność małżeństwa, Jana Paweł II sięga m.in. do klasycznego tekstu Pisma św. na ten temat z Listu św. Pawła Apostoła do Efezjan (Ef 5, 21-33). Małżeństwo ochrzczonych jest pamiątką i uobecnieniem zbawczego dzieła Chrystusa oraz rzeczywistym znakiem dzieła zbawienia, w którym małżonkowie uczestniczą jako para7. Swoje wywody o małżeństwie św. Paweł

\footnotetext{
4 FC, n. 13.

5 Por. FC, n. 20.

6 FC, n. 13.

7 Por. FC, n. 13.
} 
kończy konkluzją: „Tajemnica to wielka, a ja mówię: w odniesieniu do Chrystusa i do Kościoła" (Ef 5, 32).

W nauczaniu o małżeństwie i rodzinie sięga obficie do Pisma św. papież Franciszek w adhortacji Amoris laetitia. Pisze tam:

Przedstawiając tekst, zacznę od wprowadzenia inspirowanego Pismem św., które nada mu odpowiedni ton. Na tej podstawie rozważę aktualną sytuację rodzin, by stać twardo na ziemi. Następnie przypomnę pewne podstawowe kwestie nauczania Kościoła o małżeństwie i rodzinie (...) ${ }^{8}$.

W nauczaniu o małżeństwie i rodzinie papież Franciszek przywołuje Księgę Rodzaju: „Wspaniałe dwa pierwsze rozdziały Księgi Rodzaju przedstawiają nam parę ludzką w jej fundamentalnej rzeczywistości"9. Ukazują one małżeństwo jako nierozerwalny związek mężczyzny i kobiety, stworzonych na obraz Boży. Para ta, która kocha i rodzi życie, jest figurą zdolną ukazać Boga Stwórcę i Zbawiciela. Ta zdolność jest drogą, dzięki której kształtuje się i rozwija historia zbawienia ${ }^{10}$.

Odnowy małżeństwa dokonuje Jezus: „Jezus, który pojednał wszystko w sobie, doprowadził małżeństwo i rodzinę do ich pierwotnej formy. Rodzina i małżeństwo zostały odkupione przez Chrystusa, odtworzone na obraz Trójcy Świętej”" ${ }^{\prime \prime}$ To Jezus sprawia, że oblubieńcze przymierze, zainaugurowane podczas stworzenia, otrzymuje od Niego niezbędną łaskę za pośrednictwem Kościoła. To On rozpoczyna publiczne życie od cudu w Kanie Galilejskiej, dokonanego na przyjęciu weselnym. To Jezus odwiedza rodzinę Łazarza i jego sióstr oraz rodzinę Piotra, a także wysłuchuje płaczu rodziców opłakujących śmierć swoich dzieci

8 Franciszek, Adhortacja apostolska Amoris laetitia [dalej: AL], 19.03.2016, n. 6.

9 AL, n. 10.

10 Por. AL, n. 10-11.

$11 \mathrm{AL}, \mathrm{n} .63$. 
i przywraca je do życia. Jezus nie tylko przywrócił małżeństwo i rodzinę do ich pierwotnej roli i znaczenia, ale podniósł je także do rangi sakramentalnego znaku swojej miłości do wspólnoty Kościoła. Papież Franciszek, nauczając o sakramentalności małżeństwa, odwołuje się do Ewangelii (por. Mt 19, 1-12; Mk 10, 1-12) oraz do Listu św. Pawła Apostoła do Efezjan (Ef 5, 21-32)12. Przeprowadziwszy szeroki wywód o sakramentalności małżeństwa, papież konkluduje:

Sakrament nie jest czymś lub jakimś przymusem, ponieważ w rzeczywistości sam Chrystus przez sakrament małżeństwa pozostaje z nimi, daje im moc pójścia za Nim i wzięcia na siebie krzyża, podnoszenia się po upadkach, przebaczenia sobie wzajemnie, wzajemnego noszenia swoich ciężarów'

Papież Franciszek swoje nauczanie o małżeństwie i rodzinie osadza w tradycyjnym nauczaniu Kościoła. Sięga między innymi do doktryny Vaticanum II, zwłaszcza konstytucji Lumen gentium i Gaudium et spes, a także do nauczania posoborowych papieży: Pawła VI, Jana Pawła II i Benedykta XVI. Pisze o Janie Pawle II: „Święty Jan Paweł II poświęcił szczególną uwagę rodzinie poprzez swoje katechezy o ludzkiej miłości, list do rodzin «Gratissimam sane», a zwłaszcza przez adhortację apostolską «Familiaris consortio»"14.

Wizja małżeństwa i rodziny zaprezentowana w adhortacjach apostolskich Familiaris consortio i Amoris laetitia przesycona jest nauczaniem o miłości zaczerpniętym z Pisma św. i doktryny Kościoła. Chociaż zgodnie z tradycyjną doktryną Kościoła małżeństwo tworzy należycie wyrażona zgoda stron

\footnotetext{
12 Por. AL, n. 63, 64, 71.

13 AL, n. 73.

14 AL, n. 69.
} 
je zawierających, to jednak nigdy miłość nie była elementem drugoplanowym w małżeństwie i rodzinie ${ }^{15}$. Nauczanie Soboru Watykańskiego II dowartościowuje miłość w małżeństwie i rodzinie: „Głęboka wspólnota życia i miłości małżeńskiej ustanowiona i wyposażona w prawa przez Stwórcę, powstaje na mocy przymierza małżeńskiego, czyli nieodwołalnej zgody osobowej”16. Zgoda stron konstytuuje małżeństwo, miłość zaś kształtuje i ożywia wspólnotę małżeńską i życie rodzinne oraz nadaje im właściwy kierunek.

Sprawę miłości w małżeństwie i rodzinie podejmują przywołane wyżej adhortacje apostolskie. Jan Paweł II, nawiązując do soborowego określenia „wspólnota życia i miłości”, pisze: „W perspektywie sięgającej samych korzeni rzeczywistości małżeńskiej i rodzinnej trzeba następnie powiedzieć, że istota i zadania rodziny są ostatecznie określone przez miłość" ${ }^{17}$. Rodzina bez miłości nie może żyć, wzrastać i doskonalić się jako wspólnota osób. Miłość stanowi siłę dynamiczną, która wzmacnia i pozwala rodzinie stawać się coraz głębszą i mocniejszą jednością; jest fundamentem wspólnoty małżeńskiej i rodzinnej ${ }^{18}$. Papież konkluduje:

Człowiek nie może żyć bez miłości. Człowiek pozostaje dla siebie istotą niezrozumiałą, jego życie jest pozbawione sensu, jeśli nie objawi mu się Miłość, jeśli nie spotka się z Miłością, jeśli jej nie dotknie

15 Por. M. Żurowski, Kanoniczne prawo małżeńskie Kościoła katolickiego, Katowice 1987 , s. $73-82$.

16 Sacrosanctum Concilium Oecumenicum Vaticanum II, Constitutio dogmatica Lumen gentium de Ecclesia, 21.11.1964, AAS 57 (1965), s. 5-75; tekst łacińsko-polski: Sobór Watykański II, Konstytucja dogmatyczna o Kościele Lumen gentium, w: Sobór Watykański II, Konstytucje, dekrety, deklaracje, Poznań 20o8, s. 144-263 [dalej: KDK], n. 48.

17 FC, n. 17.

18 Por. FC, n. 18. 
i nie uczyni w jakiś sposób swoją, jeśli nie znajdzie w niej żywego uczestnictwa ${ }^{19}$.

Wielką wagę do miłości w małżeństwie i rodzinie przywiązuje papież Franciszek w adhortacji Amoris laetitia. Określenie „miłość” występuje w jej nazwie: „Radość miłości”, a także w adresie dokumentu: „Do biskupów, kapłanów i diakonów, osób konsekrowanych, do małżonków chrześcijańskich i do wszystkich wiernych świeckich o miłości w rodzinie”. Dwa rozdziały adhortacji są poświęcone miłości: rozdział IV „Miłość w małżeństwie” i rozdział V „Miłość, która staje się owocna” ${ }^{20}$. Papież pisze: „Nie możemy bowiem zachęcać do drogi wierności i wzajemnego daru z siebie, jeśli nie pobudzimy rozwoju, umocnienia i pogłębienia miłości małżeńskiej i rodzinnej”21. Papież następnie na kanwie Hymnu o miłości z 1 Listu św. Pawła Apostoła do Koryntian szeroko omawia miłość w odniesieniu do konkretnego życia rodziny (por. 1 Kor 13, 4-7) 22. Obraz kochającej się rodziny dostrzega papież także w Psalmie 128. Szczęśliwy mąż i ojciec wraz ze swoją małżonką - „płodnym szczepem winnym” - i z dziećmi - „sadzonkami oliwnymi" - zasiadają w domu wokół stołu²3.

Istota małżeństwa i jego przymioty oraz rodzina, a także miłość w rodzinie, ukazane są zarówno w adhortacji Familiaris consortio, jak i w adhortacji Amoris laetitia w oparciu o Pismo św. i nauczanie Kościoła. Podobne fundamenty jawią się w nauczaniu przywołanych adhortacji o roli i znaczeniu rodziny.

\footnotetext{
19 FC, n. 18.

20 AL, S. 71-152.

21 AL, n. 89.

22 Por. AL, n. 9o-164.

23 Por. AL, n. 8-18.
} 


\section{Rola i znaczenie rodziny}

Jan Paweł II w adhortacji Familiaris consortio nawiązuje do nauczania soborowego, że dzieci są najwspanialszym darem dla małżonków i dlatego mają oni służyć życiü²4. Pisze:

Wedle zamysłu Bożego, małżeństwo jest podstawą szerszej wspólnoty rodzinnej, ponieważ sama instytucja małżeństwa i miłość małżeńska są skierowane ku rodzeniu i wychowywaniu potomstwa, w którym znajdują swoje uwieńczenie ${ }^{25}$.

Pielęgnowanie prawdziwej miłości małżeńskiej zmierza do tego, aby małżonkowie byli nastawieni na odpowiedzialne współdziałanie z miłością Stwórcy i Zbawcy, który poprzez nich powiększa i ubogaca swoją rodzinę. Bóg zobowiązuje rodziców, aby strzegli i ochraniali życie ludzkie od samego jego początku:

Małżonkowie wiedzą, iż są współpracownikami w miłości Boga Stwórcy i jak gdyby jej interpretatorami w zakresie obowiązku przekazywania życia i wychowania, które winny być uważane za ich właściwe zadanie ${ }^{26}$.

Papież Paweł vi szeroko omawia ochronę życia ludzkiego od samego jego początku w encyklice Humanae vitae ${ }^{27}$. Potępia ona antykoncepcję, wszelkie sztuczne metody regulacji poczęć, a zwłaszcza niszczenie poczętego życia ludzkiego. Podaje także zasady etycznej regulacji poczęć ${ }^{28}$. Nauczanie Kościoła dopuszcza chrześcijańskie i odpowiedzialne planowanie rodziny i etyczną regulację poczęć, wyklucza zaś regulowanie urodzin, gdyż poczęte

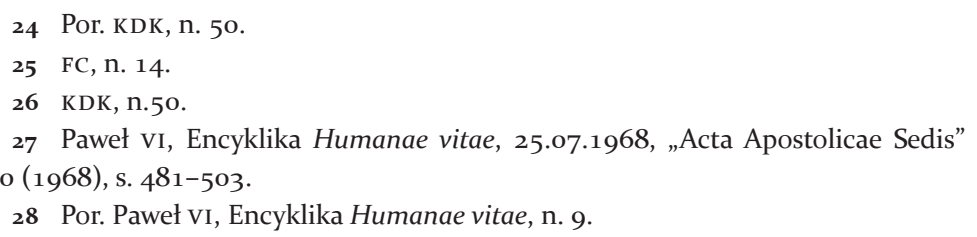


ludzkie życie na żadnym etapie swojego rozwoju nie może być niszczone ${ }^{29}$.

Jan Paweł II podejmuje zagadnienie służby życiu w jego wymiarze: przekazywania i ochrony życia, a następnie wychowania. Nazywa on rodziców współpracownikami miłości Boga Stworzyciela:

Bóg, stwarzając mężczyznę i kobietę na obraz swój i podobieństwo, wieńczy i doprowadza do doskonałości dzieło swoich rąk - powołuje ich do szczególnego uczestnictwa w swej miłości, a zarazem w swojej mocy Stwórcy i Ojca poprzez ich wolną i odpowiedzialną współpracę w przekazywaniu życia ludzkiego (... $)^{30}$.

Podstawowym zadaniem rodziny jest służba życiu i przekazywanie obrazu Bożego z człowieka na człowieka. Dlatego Kościół, depozytariusz Bożego Objawienia, broni życia, opowiada się za życiem nawet w niesprzyjającym klimacie społeczno-politycznym, nierzadko popierającym mentalność przeciwną życiu ${ }^{31}$.

Z powołania rodziców do uczestnictwa w stwórczym dziele Boga wynika obowiązek i prawo wychowania potomstwa:

Zadanie wychowania wypływa z najbardziej pierwotnego powołania małżonków do uczestnictwa w stwórczym dziele Boga: rodząc w miłości i dla miłości nową osobę, która sama w sobie jest powołana do wzrostu i rozwoju, rodzice tym samym podejmują zadanie umożliwienia jej życia w pełni ludzkiego ${ }^{32}$.

Prawo i obowiązek rodziców do wychowania są pierwotne i mają pierwszeństwo w stosunku do zadań wychowawczych innych osób i instytucji, z racji miłości ojcowskiej i macierzyńskiej, której nie

29 Por. J. Dyduch, Wiodace idee adhortacji apostolskiej „Familiaris consortio”, „Polonia Sacra” 20 (2016) nr 1, s. 131-132.

30 FC, n. 28.

31 FC, n. 28-30.

32 FC, n. 36. 
da się niczym w pełni zastąpić33. Normalny proces wychowawczy w rodzinie jest oparty o miłość, wychowuje się tam bowiem w miłości i do miłości. Człowiek ma prawo do miłości, powinien być kochanym, ale także ma obowiązek świadczyć miłość34.

Franciszek naucza w adhortacji Amoris laetitia: „Rodzina jest nie tylko środowiskiem zrodzenia, ale także przyjęcia życia jako daru, który pochodzi od Boga" ${ }^{35}$. Podkreśla także rolę matki w przyjściu na świat nowego człowieka, gdyż każde dziecko kształtujące się w łonie swej matki jest owocem odwiecznego planu Boga Ojca i Jego wiernej miłości. Matka i ojciec winni wspólnie oczekiwać na urodzenie się dziecka, winni na nie oczekiwać z miłością i radością, dlatego że jest dzieckiem. Taka miłość rodziców jest narzędziem miłości Boga Ojca, który „(...) oczekuje na narodziny każdego dziecka, bezwarunkowo je akceptuje i przyjmuje je bezinteresownie" ${ }^{36}$.

Każde dziecko ma prawo do ojca i matki, i do ich miłości. Matki są najsilniejszym antidotum na szerzący się współcześnie egoistyczny indywidualizm. Społeczeństwo bez matek byłoby społeczeństwem nieludzkim, gdyż one dają świadectwo czułości, poświęcenia, współczucia i siły moralnej. Bóg stawia ojca w rodzinie, aby był przy dziecku ze swoimi cechami męskości: odwagą, siłą, odpowiedzialnością i troskliwością w niesieniu pomocy. Zarówno postać matki, jak i ojca stanowi właściwe środowisko do przyjścia na świat i dojrzewania dziecka. Problemem rodzin naszych czasów jest częsta nieobecność ojców i uchylanie się od obowiązków ojcowskich oraz nadmierne skoncentrowanie się na sobie, swojej

33 Por. FC, n. 36-37.

34 Por. J. Krukowski, Prawa i obowiq̨zki laikatu w nowym Kodeksie Prawa Kanonicznego, „Chrześcijanin w Świecie” 15 (1983) nr 5, s. 64-65.

35 AL, n. 166.

36 Por. AL, n. 168-170. 
pracy i samorealizacji. To wszystko zakłóca należytą atmosferę rodzinną i jakoś osieroca dziecii37.

Franciszek pochwala rodziny wielodzietne, które nazywa „radością Kościoła”. Zachęca także do adopcji, nazywając ją „wielkodusznym sposobem macierzyństwa i ojcostwa”. Pochwala życie w „szerokiej rodzinie” ${ }^{8}$. Ta szeroka rodzina to także dziadkowie, wujowie, ciocie, kuzyni, a nawet sąsiedzi. Wzywa do szacunku dla starszych, którzy sprawiają, iż rodzina zachowuje pamięć historyczną o sobie, o regionie, a także o swojej ojczyźnie. To sprzyja jej rozwojowi. Jest rodziną, która ma przyszłość39.

Mówiąc o ochronie życia w rodzinie i jego przekazywaniu, papież Franciszek nawiązuje do odpowiedzialności rodziców za wychowanie swoich dzieci. Oprócz tego poświęca sprawie wychowania rozdział viI: „Umocnić wychowanie dzieci”40. Zwraca uwagę na wielowymiarowy charakter procesu wychowawczego. Rodzice powinni zająć się edukacją moralną dzieci, budując jej fundament, którym jest zaufanie. Rodzina jest pierwszą szkołą wartości ludzkich, wśród których ważne miejsce zajmuje wychowanie woli oraz rozwijanie dobrych nawyków i emocjonalnych skłonności ku dobru. Rodzice wychowują dzieci w wolności i ku wolności, stosując należną, odpowiednią do wieku dziecka dyscyplinę, z poszanowaniem jego godności. $\mathrm{W}$ wychowaniu $\mathrm{w}$ rodzinie nie można pominąć pozytywnego i mądrego wychowania seksualnego ${ }^{41}$. Rodzina ma być miejscem, w którym przekazuje się wiarę, uczy modlitwy i służby innym. Ten proces rozpoczyna się od chrztu, gdyż wiara jest darem otrzymanym od Boga w tym

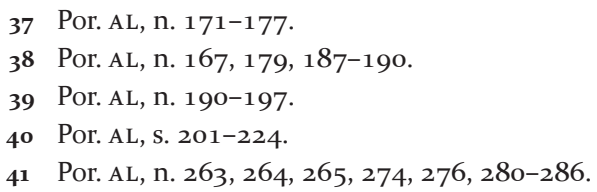


sakramencie, a rodzice są narzędziami Boga, aby ona rozwijała się i dojrzewała ${ }^{42}$.

Nauczanie soborowe o więzach łączących rodzinę z Kościołem rodzinę, która buduje Kościół - podejmuje Jan Paweł II w adhortacji Familiaris consortio. Rodzina ma być wspólnotą wierzącą i ewangelizującą: „Rodzina chrześcijańska wypełnia swoje zadanie prorockie przyjmując i głosząc Słowo Boże”43. W rodzinie wszyscy jej członkowie mają ewangelizować i podlegać ewangelizacji. Rodzice nie tylko dzielą się z dziećmi Ewangelią, ale mogą się od nich jej uczyć. Apostolska gorliwość winna towarzyszyć rodzinie, która przekazuje wiarę nie tylko wewnątrz siebie, lecz także innym rodzinom. W ten sposób rodzina jeszcze bardziej staje się wspólnotą ewangelizacyjną i apostolską jako „Kościół domowy”. Rodzina „Kościół domowy” - jest włączona w posługę uświęcającą, spełnia ją głównie poprzez uczestnictwo w sakramentach oraz modlitwę, zwłaszcza wspólną ${ }^{44}$. Szczególnym przejawem apostolskiej i uświęcającej roli rodziny jest troska i pielęgnowanie powołań kapłańskich, zakonnych i misyjnych ${ }^{45}$. Rodzina jest pierwszą i żywotną komórką społeczeństwa, w rodzinie rodzą się bowiem obywatele i tam znajdują pierwszą szkołę cnót społecznych. Rodzina stanowi kolebkę i skuteczne narzędzie humanizacji i personalizacji społeczeństwa, jest strażnikiem cnót i wartości społecznych, buduje i jednoczy społeczeństwa. Dlatego rodzina zasługuje na wieloraką pomoc państwa: gospodarczą, społeczną, pedagogiczną, polityczną i kulturalną, która jest niezbędna do tego, aby mogła w sposób należyty sprostać swojej odpowiedzialnej roli ${ }^{46}$.

\footnotetext{
42 Por. AL, n. 287-289.

43 FC, n. 51.

44 Por. FC, n. 52-62.

45 Por. N. Martin, Die Familie nach „Familiaris consortio”, das erste und beste Seminar fur geistliche Berufe, „Seminarium” 23 (1983), s. 185-195.

46 Por. FC, n. 42-46.
} 
Franciszek w adhortacji Amoris laetitia naucza o wzajemnym przenikaniu Kościoła i rodzin:

Kościół jest rodziną rodzin, stale wzbogacającą życie wszystkich Kościołów domowych. W związku z tym na mocy sakramentu małżeństwa każda rodzina staje się dobrem dla Kościoła ze wszystkimi tego skutkami. Kościół jest dobrem dla rodziny, rodzina jest dobrem dla Kościoła ${ }^{47}$.

W rodzinie ludzie uczą się miłości braterskiej, wzajemnego przebaczenia, a także oddawania czci Bogu przez modlitwę i ofiarę swojego życia. W sakramencie małżeństwa małżonkowie są jakby konsekrowani, by dzięki danej im łasce budowali Kościół - ciało Chrystusa ${ }^{4}$. Rodzina jest wezwana do ewangelizacji, a także do wspólnej codziennej modlitwy, czytania słowa Bożego, regularnego uczestniczenia we Mszy Świętej, przystępowania do sakramentów, w szczególności do częstego przystępowania do sakramentu pokuty i Komunii św., aby rozwijać miłość i coraz bardziej stawać się świątynią, w której mieszka Duch św. ${ }^{49}$

Rodzina ma prawo do pomocy państwa, gdyż jest pierwszą szkołą wartości ludzkich i należytego korzystania z wartości, a także podstawowym środowiskiem cnót społecznych. Ważną pomocą dla rodziny są szkoły, o które zadbać ma państwo, w tym ma ono wspierać także szkoły katolickie. Rodzina ma prawo oczekiwać od władz publicznych właściwej polityki prorodzinnej ${ }^{50}$.

Obydwie omawiane adhortacje stoją na straży życia ludzkiego, a także ukazują rolę małżeństw i rodzin w budowaniu wspólnoty Kościoła i wspólnoty politycznej.

\footnotetext{
47 AL, n. 87.

48 Por. AL, n. 15, 67, 86.

49 Por. AL, n. 205-216, 29, 43, 184, 227.

5o Por. AL, n. 257, 276, 43-44, 279.
} 


\section{Sytuacje nieprawidłowe i nieregularne w perspektywie duszpasterskiej}

Omawiane adhortacje apostolskie zajmują się także kryzysem, który współcześnie dotyka małżeństwa i rodziny, oraz związanym z tym zamieszaniem w ich życiu. Adhortacja Familiaris consortio wymienia następujące sytuacje nieprawidłowe: a) małżeństwo na próbę; b) rzeczywiste wolne związki; c) katolicy złączeni tylko ślubem cywilnym; d) żyjący w separacji i rozwiedzeni, którzy nie zawarli nowego związku; e) rozwiedzeni, którzy zawarli nowy związek. Małżeństwo na próbę usprawiedliwiają niektórzy tym, jakoby związek ten miał przygotować do małżeństwa, dlatego traktuje się je jako eksperyment. Założenia te są błędne choćby z tego względu, że człowiekiem nie można eksperymentować, gdyż uwłacza to jego godności. Również jest to sprzeczne z religijną wizją nierozerwalnego małżeństwa, które jest obrazem miłości Chrystusa do Kościoła ${ }^{51}$.

Rzeczywiste wolne związki stanowią taką koncepcję związków małżeńskich, która nie uznaje żadnej ich publicznej więzi instytucjonalnej - ani cywilnej, ani religijnej. Zjawisko to ma różne przyczyny. Należą do nich m.in. trudne sytuacje ekonomiczne, kulturowe i religijne. Takie związki są sprzeczne z dobrem Kościoła i społeczeństwa, a także są zagrożeniem dla dobra potomstwa ${ }^{52}$. Inną formą sytuacji nieprawidłowych jest zawieranie przez katolików tylko związków cywilnych, tak zwanych ślubów cywilnych, z pominięciem ślubu kościelnego. Wynika to najczęściej z obojętności religijnej, czasem z powodów ekonomicznych. Przejawia się nieraz jako odrzucenie małżeństwa religijnego albo jako jego odkładanie ${ }^{53}$. Katolików żyjących w małżeństwach na próbę, rze-

\footnotetext{
51 Por. FC, n. 80.

52 Por. FC, n. 81.

53 Por. FC, n. 82.
} 
czywistych wolnych związkach czy tylko w związkach cywilnych nie można dopuścić do sakramentów, dopóki nie uregulują swojej sytuacji.

Inaczej należy traktować osoby żyjące w separacji, jeśli przeprowadzona jest ona zgodnie z przepisami prawa kanonicznego (por. Kodeks prawa kanonicznego [dalej: KPK 1983], kan. 1692-1696). Wspólnota kościelna winna otoczyć szacunkiem i pomocą małżonka odseparowanego, zwłaszcza gdy nie ponosi on winy za zaistniałą sytuację ${ }^{54}$. Separacja małżonków jest zerwaniem przez nich osobowej wspólnoty małżeńskiej na podstawie przyczyny prawnej, z zachowaniem nadal węzła małżeńskiego. Nie upoważnia ona do zawarcia kolejnego małżeństwa, a wręcz przeciwnie - suponuje wznowienie wspólnego pożycia małżeńskiego ${ }^{55}$. Małżonek rozwiedziony, świadomy nierozerwalności ważnego węzła małżeńskiego, niezawierający nowego związku, ma być dopuszczony do sakramentów, gdyż taki wybór jest świadectwem wierności i chrześcijańskiej odpowiedzialności ${ }^{56}$.

Rozwiedzeni, którzy zawarli ponowny związek, nie są odłączeni od wspólnoty Kościoła i powinni uczestniczyć w jego życiu w takim wymiarze, na jaki pozwala ich aktualna sytuacja. Nadal mają być przedmiotem troski i modlitwy Kościoła oraz duszpasterzy. Nie mogą jednak przystępować do sakramentu pokuty i do Komunii eucharystycznej. To byłoby możliwe wówczas, jeśliby żałując naruszenia wierności Chrystusowi i znaku przymierza, podjęli życie w pełnej wstrzemięźliwości małżeńskiej, mając także ważne powody pozostania razem, na przykład wychowanie dzieci57.

54 Por. FC, n. 83.

55 Por. T. Pawluk, Prawo kanoniczne wedtug Kodeksu Jana Pawła II, t. 4, Olsztyn 1990, s. 331-332.

56 Por. FC, n. 83.

57 Por. FC, n. 84. 
Franciszek w adhortacji Amoris laetitia zajmuje się sytuacjami nieregularnymi w małżeństwie i rodzinie. W kilku przypadkach ich rozwiązania odwołuje się do papieża Jana Pawła II i jego adhortacji Familiaris consortio, na przykład separację małżonków uznaje za środek ostateczny ${ }^{58}$; także w sprawie traktowania małżonków rozwiedzionych, którzy nie zawierają nowego związku ${ }^{59}$. Również stawia podobną tezę o szacunku i pomocy dla osób rozwiedzionych, które zawarły ponowny związek:

Ważne, aby osoby rozwiedzione i żyjące w nowych związkach odczuwały, że są częścią Kościoła, że nie są ekskomunikowane i nie są traktowane jako takie, bo zawsze tworzą wspólnotę kościelną. Sytuacje te wymagają uważnego rozeznania i towarzyszenia $(. . .)^{60}$.

Drogą Kościoła jest ofiarowanie miłosierdzia Bożego tym, którzy szczerze o to proszą, a nie droga potępiania. Nikt nie może być potępiony na zawsze, gdyż nie taka jest logika Ewangelii ${ }^{61}$. Ta droga charakteryzuje się rozeznaniem i towarzyszeniem:

W odniesieniu do różnych sytuacji, zwanych nieregularnymi, ojcowie synodalni osiągnęli ogólny konsens, który popieram, by podejść duszpastersko do osób, które zawarły małżeństwo cywilne, rozwiedzionych żyjących w nowych związkach, lub które jedynie mieszkają razem, obowiązkiem Kościoła jest ukazanie im pedagogii łaski w ich życiu i dopomożenie im w osiągnięciu pełni planu Bożego, co jest zawsze możliwe z mocą Ducha Świętego ${ }^{62}$.

To rozeznanie duszpasterskie winno rozróżniać sytuacje nieregularne, na przykład osób, które czyniły wielkie wysiłki, aby

\footnotetext{
58 Por. AL, n. 241.

59 Por. AL, n. 242.

60 AL, n. 243.

61 Por. AL, n. 296-297.

62 AL, n. 297.
} 
uratować pierwsze małżeństwo, i doznały niesprawiedliwego porzucenia ${ }^{63}$.

Franciszek wprowadza w adhortacji Amoris laetitia stopniowość, sięgając do Familiaris consortio. Sprawia ona, iż człowiek poznaje i czyni dobro moralne odpowiednio do etapów swojego rozwoju ${ }^{64}$. Adhortacja Amoris laetitia przywołuje możliwość przystąpienia do sakramentów świętych rozwiedzionych, którzy zawarli ponowny związek, określoną w adhortacji Familiaris consortio $^{65}$. Wydaje się jednak, że adhortacja Amoris laetitia jak gdyby pragnęła te możliwości poszerzyć, nie określając tego dokładnie ${ }^{66}$. Trzeba dodać, iż papież Franciszek w adhortacji nie mówi ani o zasadach, ani o konkretnych okolicznościach dopuszczenia do sakramentów osób rozwiedzionych, które zawarły ponowny związek. Wielokrotnie natomiast przywołuje zasadę nierozerwalności sakramentalnego małżeństwa ${ }^{67}$. Dlatego ważna jest interpretacja przywołanej adhortacji. W szczególności sprawa dopuszczenia rozwiedzionych do sakramentów wymaga zarówno interpretacji naukowej, dokonywanej przez ekspertów, jak i urzędowej, dokonywanej głównie przez konferencje biskupie. Podobnej interpretacji potrzebować będzie stwierdzenie:

Ich (rozwiedzionych) udział może wyrażać się w różnych posługach kościelnych: trzeba rozeznać, które z różnych form wykluczenia obecnie praktykowanych w dziedzinie liturgicznej, duszpasterskiej, edukacyjnej oraz instytucjonalnej można przezwyciężyćc ${ }^{\text {. }}$.

\footnotetext{
63 Por. AL, n. 298.

64 Por. AL, n. 295.

65 Por. AL, n. 298.

66 Por. AL, przypis 329 i 351, n. 298, 302, 303, 305.

67 Por. AL, n. 71-75, 292.

68 AL, n. 299.
} 
Na przykład: czy można by dopuścić do funkcji chrzestnego osobę rozwiedzioną? Albo do udziału w radzie duszpasterskiej?

Trzeba zauważyć, że adhortacja Familiaris consortio jasno określa możliwości dopuszczenia osób żyjących w związkach nieprawidłowych do korzystania z sakramentów. Przypadki te są wyjątkowe. Natomiast adhortacja Amoris laetitia przywołuje rozwiązania adhortacji Jana Pawła II, ale wczuwając się w dramatyczną sytuację katolików rozwiedzionych, którzy zawarli nowe związki, odwołując się do miłosierdzia Bożego, prowadzi rozważania sugerujące poszerzenie tych możliwości. Nie określa tego w sposób precyzyjny i dlatego pozostawia sytuację otwartą, wymagającą dalszych dyskusji i rozstrzygnięć. Wydaje się, iż sprawę tę podejmą konferencje biskupie, które winny postarać się o poprawność doktrynalną i jednolitość rozstrzygnięć w kwestiach związanych z wiarą i moralnością.

Biskupi polscy, uczestnicy XIV Zwyczajnego Zgromadzenia Ogólnego Synodu Biskupów (4-25 października 2015 roku), w swoich wypowiedziach podczas synodu i po jego zakończeniu podkreślali, że dotychczasowa dyscyplina dopuszczenia katolików rozwiedzionych do sakramentów pozostaje bez zmian. Wydaje się, że po opublikowaniu adhortacji Amoris laetitia zaistniała potrzeba przygotowania i opublikowania dokumentu Konferencji Episkopatu Polski podającego i uzasadniającego rozstrzygnięcie tego tematu.

\section{Zakończenie}

Zarówno adhortacja Familiaris consortio, jak i adhortacja Amoris laetitia wpisują się w nauczanie Kościoła o małżeństwie i rodzinie. Ta druga jest kontynuacją pierwszej, gdyż odwołuje się do niej dziewiętnaście razy; również z tego względu, że omawia te same zagadnienia, na przykład: małżeństwo i rodzina w nauczaniu Biblii i Urzędu Nauczycielskiego Kościoła, miłość w rodzinie, zadania 
i rola rodziny, kryzys małżeństwa i jego przejawy, wyrażające się również w związkach nieprawidłowych czy nieregularnych. Dlatego na pytanie postawione w temacie artykułu - czy jest to kontynuacja twórcza? - trzeba odpowiedzieć: zdecydowanie tak! Czego nie omieszkaliśmy zaznaczyć tu i ówdzie w treści artykułu.

Na osobną uwagę zasługuje obszerny komentarz w adhortacji Amoris laetitia do Hymnu o miłości św. Pawła Apostoła, na kanwie którego papież zaprezentował znaczenie miłości w małżeństwie i rodzinie. Podobnie ważne jest podkreślenie przez papieży duchowości małżeńskiej i rodzinnej. Trudny temat dopuszczenia do sakramentów katolików żyjących w związkach niesakramentalnych adhortacja Amoris laetitia pozostawia otwarty, wymagający dopracowania.

Obydwie zaprezentowane adhortacje stanowią konstruktywny wkład w nauczanie o małżeństwie i rodzinie. Zadaniem zaprezentowanego artykułu było jedynie porównanie niektórych zagadnień w nich poruszonych, nie zaś ocena wartości omawianych adhortacji.

\section{SUMMARY}

\section{Is apostolic exhortation Amoris laetitia a creative continuation of apostolic exhortation} Familiaris consortio?

Both apostolic exhortations Amoris laetitia of Pope Francis and Familiaris consortio of pope John Paul II are deeply rooted in the Bible and the teaching of the Magisterium. The two documents in question present mainly: marriage and family love and the role and tasks of service for life and building church and secular community. The difficult problem of admission 
of divorced and re-married Catholics to sacraments was solved in Familiaris consortio, but Amoris laetitia left the problem open as a problem that requires further investigation, discussion and settlements.

Keywords: marriage, family, love in family, service for life, education, irregular unions, dis-concernment, assistance

Jan Dyduch, Adhortacja „Amoris laetitia” twórczq kontynuacją adhortacji „Familiaris consortio”?, w: Dyskusje nad „Amoris laetitia”, red. Piotr Kroczek, Kraków 2017, s. 27-46 (Annales Canonici Monographiae, 6).

DOI: http://dx.doi.org/10.15633/9788374386463.03 